Fixed Point Theory, 18(2017), No. 2, 545-554

DOI 10.24193/fpt-ro.2017.2.42

http://www.math.ubbcluj.ro/ nodeacj/sfptcj.html

\title{
CONVERGENCE OF MANN'S ITERATION FOR RELATIVELY NONEXPANSIVE MAPPINGS
}

\author{
A. ANTHONY ELDRED AND A. PRAVEEN \\ P.G and Research Department of Mathematics \\ St.Joseph's College, Tiruchirappalli-2 \\ Tamilnadu, India \\ E-mail: anthonyeldred@yahoo.co.in and prawin4jesus@gmail.com
}

\begin{abstract}
We consider the Mann's iterative process to approximate the fixed points and best proximity points of a relatively non-expansive mapping $T: A \cup B \rightarrow A \cup B$, satisfying $\|T x-T y\| \leq\|x-y\|$ $\forall x \in A, y \in B$. These mappings need not be continuous.

Key Words and Phrases: Von Neumann sequences, relatively nonexpansive mappings, best proximity points, fixed points.

2010 Mathematics Subject Classification: 47H10, 54H25.

\section{REFERENCES}

[1] A. Anthony Eldred, W.A. Kirk, P. Veeramani, Proximal normal structure and relatively nonexpansive mappings, Studia Math., 171(2005), no. 3, 283-293.

[2] A. Anthony Eldred, P. Veeramani, Existence and convergence of best proximity points, J. Math. Anal. Appl., 323(2006), 1001-1006.

[3] H.H. Bauschke, J.M. Borwein, On the Convergence of von Neumann's alternating projection algorithm for two sets, Set-Valued Anal., 1(1993), 185-212.

[4] C.E. Chidume, Geometric Properties of Banach Spaces and Nonlinear Iterations, London, Springer, 2009

[5] H.S. Hundal, An alternating projection that does not converges in norm, Nonlinear Anal., $\mathbf{5 7}(2004), 35-61$.

[6] H.F. Senter, W.G. Dotson, Approximating fixed points of nonexpansive mappings, Proc. Amer. Math. Soc., 44(1974), 375-380.

[7] J. von Neumann, Functional Operators, Vol. II, Princeton University Press, 1950.
\end{abstract}

Received: November 27, 2014; Accepted: October 8, 2015. 